\title{
The Effect of Lifestyle on Primary Dysmenorrhea
}

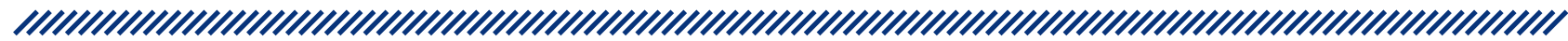

1 Monika Finžgar

2 Raja Dahmane Gošnak

3 Borut Poljšak

4 Andrej Starc

1 Faculty of Health Sciences, University of Ljubljana

2 Faculty of Health Sciences, University of Ljubljana, Department of Biomedicine in Health Care

3 Faculty of Health Sciences, University of Ljubljana, Laboratory for Oxidative Stress Research

4 Faculty of Health Sciences, Department of Public Health, Slovenia, University of Ljubljana

\section{Abstract}

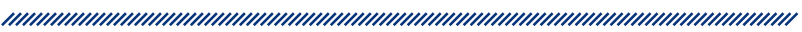

Introduction: Dysmenorrhea, also known as painful periods, is a common gynaecological diagnosis faced by most women of fertile age. Dysmenorrhea is still a misunderstood condition and most women accept it as a normal part of their menstrual cycle. The pain has a strong impact on well-being and can severely affect quality of life.

Methods: An online questionnaire was administered to female subjects between May and July 2020. ShapiroWilk, Mann-Whitney and Kruskal-Wallis tests were used, non-para-medical statistical analyses using Spearman correlation coefficient. Statistical significance was set at $\mathrm{p} 0.05$.

Results: The sample consisted of 774 women. It can be seen that the respondents who have already given birth have statistically significantly less menstrual pain $(M R=270.36 ; V R=67859.50)$ than the respondents who have not given birth ( $M R=402.06 ; \mathrm{VR}=184545.50)$. On average, respondents who experience orgasm less than $1 x /$ week ( $M R=346.93)$ have the least menstrual pain, and respondents who experience orgasm daily or 4-6x/ week have the most menstrual pain (MR $=427.18)$. Respondents who go to bed at lam or later have the highest mean pain response score $(M R=433.65)$ and the lowest among those who go to bed before $10 \mathrm{pm}$ (MR = 346.30). The highest mean menstrual pain response score is among respondents who have negative attitude towards menstruation ( $M R=557.54)$ and the lowest is among respondents who have neutral attitude (MR $=268.82)$.

Conclusions: The results confirm statistically significant relationships between sleep, sexuality, stress, menstrual perception and menstrual pain.

Keywords: menstrual pain, lifestyle, dysmenorrhea, lifestyle factors.

Article received: 22.6.2021.

Article accepted: 1.11.2021.

https://doi.org/10.24141/1/8/1/5

Corresponding author:

Andrej Starc

Faculty of Health Sciences, Department of Public Health, Slovenia, University of Ljubljana

Zdravstvena pot 5, 1000 Ljubljana, Slovenia 


\section{Introduction}

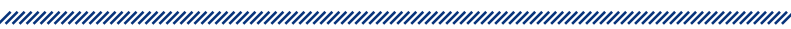

Painful menstruation or dysmenorrhea occasionally affects the majority of the female population of childbearing age ${ }^{1-8}$. Primary dysmenorrhea is still a relatively unexplored area and a poorly understood disorder. Women differ in terms of their genetic material, anatomical characteristics, and also in terms of everyday factors such as level of physical activity, stress, frequency of sexual intercourse, diet, etc.

Studies on primary dysmenorrhea have shown a strong correlation between factors such as cycle length, diet, physical activity, sexuality and the occurrence of menstrual pain. The authors cite prolonged menstruation (more than five days) and a cycle longer than 29 days as risk factors for dysmenorrhea. Eating larger amounts of sugar, salty snacks, coffee, juices, obesity, skipping meals and breakfast, early menarche, heavy menstruation, and the presence of dysmenorrhea in close relatives have also been shown to be negative factors for the occurrence of pain. Physical activity, late menarche, and sexual activity have been shown to have a positive effect on menstrual pain ${ }^{2,9-12}$.

\section{Methodology}

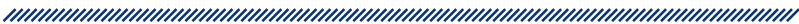

The study was conducted on female subjects. We conducted an online survey and the study was conducted according to the principles of the Declaration of Helsinki. The online survey began in May and ended in July 2020. To exclude the likelihood of secondary dysmenorrhea, we excluded all participants with endometriosis, adenomyosis, fibroids (fibromas), cervical stenosis, and pelvic inflammatory disease. Based on the outcome, nonparametric statistical tests were used in all subsequent analyses. Of the 1521 invitations, 984 were returned; 774 were fully completed and 210 were partially completed. Only the fully completed questionnaires were considered for statistical analysis. The final sample included 774 female participants; the sample realization was $78.7 \%$.

\section{Results}

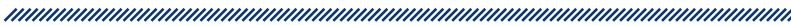

The sample included respondents in the following age groups: $21-25$ years $(n=274 ; 35.4 \%), 26-30$ years $(n=178$; $23.0 \%)$, and $31-35$ years $(n=115 ; 14.9 \%)$. Almost half of the respondents live in villages ( $n=335 ; 43.3 \%)$, about one-third live in cities ( $n=258 ; 33.3 \%$ ), and almost onefourth live in suburbs $(n=181 ; 23.4 \%))$. Most participants have completed vocational training or secondary school ( $n=310 ; 40.1 \%)$ and have a $1^{\text {st }}(n=216 ; 27.9 \%)$ or $2 n d$ level $(n=129 ; 16.7 \%)$ university degree (Table 1$)$.

\section{Table 1. Demographic data.}

\begin{tabular}{|c|c|c|c|}
\hline $\begin{array}{c}\text { Demographic } \\
\text { data }\end{array}$ & Answers & $\mathrm{f}$ & $\%$ \\
\hline & up to 15 years & 3 & 0.4 \\
\hline & $16-20$ years & 56 & 7.2 \\
\hline & $21-25$ years & 274 & 35.4 \\
\hline & $26-30$ years & 178 & 23.0 \\
\hline & $31-35$ years & 115 & 14.9 \\
\hline & $36-40$ years & 67 & 8,7 \\
\hline & $41-45$ years & 38 & 4.9 \\
\hline & $46-50$ years & 29 & 3.7 \\
\hline & 51 years and more & 14 & 1.8 \\
\hline & Total & 774 & 100 \\
\hline \multirow{4}{*}{ Location } & City & 258 & 33.3 \\
\hline & Suburbs & 181 & 23.4 \\
\hline & Village & 335 & 43.3 \\
\hline & Total & 774 & 100 \\
\hline \multirow{9}{*}{$\begin{array}{l}\text { Level of } \\
\text { education }\end{array}$} & $\begin{array}{l}\text { Unfinished } \\
\text { primary education }\end{array}$ & 2 & 0.3 \\
\hline & Primary education & 13 & 1.7 \\
\hline & $\begin{array}{c}\text { Lower or middle } \\
\text { vocational education }\end{array}$ & 31 & 4.0 \\
\hline & $\begin{array}{c}\text { Secondary professional, } \\
\text { secondary general } \\
\text { education }\end{array}$ & 310 & 40.1 \\
\hline & University degree & 49 & 6.3 \\
\hline & $1^{\text {st }}$ level university degree & 216 & 27.9 \\
\hline & $2^{\text {nd }}$ level university degree & 129 & 16.7 \\
\hline & $3^{\text {th }}$ level university degree & 24 & 3.1 \\
\hline & Total & 774 & 100 \\
\hline
\end{tabular}


Almost half of the respondents answered that menstruation is a nuisance but should be so ( $n=351 ; 45.3 \%)$, about one third thinks that menstruation is something natural and feminine $(n=254 ; 32.8 \%)$. The rest do not care because menstruation comes and goes $(n=112$; $14.5 \%$ ) or they do not like it and wish they did not have it $(n=57 ; 7.4 \%)$. In the sample, menstruation occurred for the first time at ages 11 to 13 years $(n=563 ; 72.7 \%)$, 14 to 16 years ( $n=157 ; 20.3 \%$ ), and for a smaller proportion at ages 8 to 10 years $(f=47 ; 6.1 \%)$ or at another age $(\mathrm{n}=7 ; 0.9 \%)$. The majority had regular menstruation ( $\mathrm{n}$ $=685 ; 88.5 \%$ ), and the small proportion did not have a regular menstrual cycle $(n=89 ; 11.5 \%)$. For the majority, menstruation lasted an average of four to seven days ( $\mathrm{n}$ $=673 ; 87.0 \%)$, up to three days ( $n=58 ; 7.5 \%)$, or eight or more days $(n=43 ; 5.6 \%)$ (Table 2$)$.

Most respondents were in heterosexual $(n=727 ; 93.9 \%)$, homosexual $(n=16 ; 2.1 \%)$, and bisexual $(n=30 ; 3.9 \%)$ relationships. One respondent was pansexual (0.1\%). Respondents were sexually active or had already had sexual intercourse ( $n=711 ; 91.9 \%)$, while others were not sexually active $(n=62 ; 8.1 \%)$. Respondents who were sexually active were asked the age of their first sexual intercourse. Most were 16-18 years old ( $n=396 ; 55.8 \%), 19-21$ years old $(n=161 ; 22.7 \%), 13-15$ years old $(n=98 ; 13.8 \%)$, and $22-24$ years old $(n=41,5.8 \%)$. Twelve respondents were 25 years and older $(n=12 ; 1.7 \%)$ and $11-13$ years old $(n=2 ; 0.3 \%)$. Respondents who were sexually active were asked how often they had sexual intercourse in the past six months. Respondents had sexual intercourse two to four times/week ( $n=245 ; 34.5 \%)$, once/week $(n=187$; $26.3 \%)$, and one to three times/month ( $n=149 ; 21.0 \%$ ), $55(7.7 \%)$ had sexual intercourse less than once/month, 21 respondents (3.0\%) were sexually active five times or more/week, and 53 respondents (7.5\%) had no sexual intercourse (Table 3).

\begin{tabular}{|c|c|c|}
\hline & $\mathrm{f}$ & $\%$ \\
\hline Less than 1 time/month & 55 & 7.7 \\
\hline 1 to 3 times/month & 149 & 21.0 \\
\hline 1 time/week & 187 & 26.3 \\
\hline 2 to 4 times/week & 245 & 34.5 \\
\hline 5- and more times/week & 21 & 3.0 \\
\hline $\begin{array}{l}\text { I haven't had sex in the last six } \\
\text { months }\end{array}$ & 53 & 7.4 \\
\hline Missing & 1 & 0.1 \\
\hline Total & 711 & 100 \\
\hline
\end{tabular}

\begin{tabular}{|c|c|c|c|}
\hline \multicolumn{2}{|c|}{ Table 2. Descriptive statistics of questions about menstruation in general. } \\
\hline Questions & Answers & $\mathrm{f}$ & $\%$ \\
\hline \multirow{2}{*}{$\begin{array}{c}\text { How do you experience } \\
\text { menstruation? }\end{array}$} & It is something natural, feminine, I am proud and happy to have it & 254 & 32.8 \\
\hline & It is a nuisance, but that's the way it has to be & 351 & 45.3 \\
\hline & I don't like it, I wish I didn't have it & 57 & 7.4 \\
\hline $\begin{array}{c}\text { At what age did you first } \\
\text { have your period? }\end{array}$ & I don't care, it comes and goes & 112 & 14.5 \\
\hline & Total & 774 & 100 \\
\hline $\begin{array}{c}\text { Do you have regular } \\
\text { periods? (every month or } \\
\text { every 21 to 35 days)? }\end{array}$ & $8-10$ & 47 & 6.1 \\
\hline & $11-13$ & 563 & 72.7 \\
\hline & $14-16$ & 157 & 20.3 \\
\hline $\begin{array}{c}\text { How many days does your } \\
\text { period last on average? }\end{array}$ & Other & 7 & 0.9 \\
\hline & Total & 774 & 100 \\
\hline & Yes & 685 & 88.5 \\
\hline
\end{tabular}


Respondents who had been sexually active in the past six months were asked about the relationship between menstrual irregularities and their sexual activity. In the sample, 362 (55.1\%) did not have sex during menstruation, 192 $(29.2 \%)$ rarely had sex during menstruation, followed by the responses "I am sexually active during menstruation as always" ( $n=54 ; 8.2 \%)$ and "During menstruation, I have a greater need for sex and am more active" ( $n=49 ; 7.5 \%)$.

Two hundred and fifty-one respondents had already given birth $(n=251 ; 35.3 \%)$ and $459(64.6 \%)$ had not. The largest proportion of respondents who had already given birth had two children ( $n=122 ; 48.6 \%)$ (Table 4$)$.

\begin{tabular}{|c|c|c|c|}
\hline \multicolumn{4}{|c|}{ Table 4. Number of births } \\
\hline Questions & Responses & $\mathrm{f}$ & $\%$ \\
\hline \multirow{2}{*}{$\begin{array}{c}\text { Did you have a } \\
\text { give birth? }\end{array}$} & Yes & 251 & 35.3 \\
\hline & Missing & 459 & 64.6 \\
\hline & Total & 711 & 0.1 \\
\hline \multirow{2}{*}{ Number of births } & 1 & 4 & 100 \\
\hline & 2 & 122 & 47.5 \\
\hline & 3 & 30 & 12 \\
\hline & 4 & 4 & 1.6 \\
\hline & 10 & 1 & 0.4 \\
\hline
\end{tabular}

In the sample, less than half of all respondents experience orgasm one to three times per week ( $n=335 ; 43.3 \%), 158$ (20.4\%) experience orgasm less than once per week, followed by 104 of all respondents who experience orgasm four to six times per week (13.4\%), 86 (11.1\%) experience orgasm once/month or less, and 38 (4.9\%) have not experienced orgasm in the past six months. Seven respondents $(0.9 \%)$ experience orgasm every day. Only a small proportion of respondents had never experienced an orgasm (n = 46; 5.9\%). The majority, 728 (94.1\%), had experienced orgasm (Table 5).

\begin{tabular}{|c|c|c|c|}
\hline & & $\mathrm{f}$ & $\%$ \\
\hline \multirow{8}{*}{$\begin{array}{c}\text { The frequency } \\
\text { of orgasm }\end{array}$} & Every day & 7 & 0.9 \\
\hline & 4-6 times/week & 104 & 13.4 \\
\hline & 1-3 times/week & 335 & 43.3 \\
\hline & less than 1 time/week & 158 & 20.4 \\
\hline & 1 time/month or less & 86 & 11.1 \\
\hline & $\begin{array}{c}\text { I have not had an } \\
\text { orgasm in the past six } \\
\text { months }\end{array}$ & 38 & 4.9 \\
\hline & & 46 & 5.9 \\
\hline & Total & 774 & 100 \\
\hline
\end{tabular}

The largest proportion of respondents usually experience one orgasm during sexual intercourse $(n=465$; $63.9 \%)$, two ( $n=18325.1 \%)$, followed by $49(6.7 \%)$ who experience three or more orgasms and 27 respondents who usually do not experience orgasm (3.7\%) (Table 6).

\begin{tabular}{|c|c|c|c|}
\hline \multicolumn{4}{|c|}{$\begin{array}{c}\text { Table 6. Number of orgasms during one } \\
\text { sexual intercourse or masturbation }\end{array}$} \\
\hline & 1 & f & $\%$ \\
\hline & 2 & 465 & 63.9 \\
\hline $\begin{array}{c}\text { How many orgasms } \\
\text { do you usually }\end{array}$ & 3 and more & 183 & 25.1 \\
\hline $\begin{array}{c}\text { experience during } \\
\text { sexual intercourse } \\
\text { or masturbation? }\end{array}$ & $\begin{array}{c}\text { Usually I don't } \\
\text { experience an orgasm }\end{array}$ & 27 & 6.7 \\
\hline & Missing & 4 & 0.5 \\
\hline & Total & 728 & 100 \\
\hline
\end{tabular}

Respondents then answered questions about the sensation of pain during menstruation on a ten-point scale, with 1 representing "not painful" and 10 representing "very painful menstruation." On average, respondents reported that their menstruation was moderately painful in the last six months $(M=4.96 ; S D=$ 2.649; $\mathrm{Me}=5.00$ ). Before the first day of menstruation, respondents' pain was low on average $(M=3.47$; $S D=$ 2.661; $\mathrm{Me}=2.50$ ), and on the first day of menstruation it was moderate $(M=5.23 ; S D=2.904 ; M e=5.00)$. On the second day of menstruation, respondents' pain was on average equal $(M=4.10 ; S D=2.718 ; M e=4.00)$, and after the second day of menstruation, pain was on average mild $(\mathrm{M}=2.32 ; \mathrm{SD}=1.902 ; \mathrm{Me}=1.00)$.

Almost half of the respondents reported that some of their immediate family members had painful menstruation ( $n=342 ; 44.2 \%)$ and $312(40.3 \%)$ answered that this was not the case. The remaining 120 (15.5\%) respondents answered that they did not know if their family members suffered from painful menstruation. More than half, 396 (51.2\%) of the respondents, answered that they thought more pain was not associated with heavier menstrual bleeding, and less than half of the respondents agreed with this statement ( $\mathrm{n}$ $=378 ; 48.8 \%$ ).

Majority of the respondents do not take painkillers before/during menstruation ( $n=420 ; 54.3 \%$ ), and $354(45.7 \%)$ respondents take painkillers. About twothirds of the respondents do not suffer from menstrual pain $(n=512 ; 66.1 \%)$ and one-third do not let the pain interfere with their daily tasks ( $n=262 ; 33.9 \%$ ). 


\begin{tabular}{|c|c|c|c|}
\hline \multicolumn{4}{c}{$\begin{array}{c}\text { Table 7. Kruskal-Wallis test of menstrual pain according to } \\
\text { the frequency of experiencing orgasms }\end{array}$} \\
\hline $\begin{array}{c}\text { Pain during } \\
\text { menstruation }\end{array}$ & $\begin{array}{c}\text { Frequency of experiencing orgasms } \\
\text { Every day or 4-6 times / week }\end{array}$ & f & MR \\
\hline $\begin{array}{c}\text { How painful are your } \\
\text { periods on average } \\
\text { (last 6 months). }\end{array}$ & $1-3$ times/week & 335 & 427,18 \\
\hline & less than 1 time/week & 158,15 & 346,93 \\
\hline
\end{tabular}

Respondents who had exercised in the past six months ( $n=667$ ) were asked how often they exercised per week. Less than one-third of respondents exercise once per week (31.3\%), $315(47.2 \%)$ exercise two to three times per week, 105 (15.7\%) exercise four to five times per week, and 38 (5.7\%) respondents exercise six to seven times per week. Respondents who exercised in the last six months were also asked if they exercised during menstruation. More than half are active during menstruation $(n=385 ; 57.7 \%)$, and less than half are not active during menstruation $(\mathrm{n}=$ $282 ; 42.3 \%)$.

To test the effects of sugar consumption and salty snacks, we chose to use a nonparametric KruskalWallis test based on the results of normality of responses to menstrual pain. We used the Kruskal-Wallis test to test for statistically significant differences in mean ranges/mean scores of menstrual pain as a function of frequency of sugar and salty snack consumption (never, up to 3 times/month, 1-2 times/ week, 3-6 times/week, 1/day, several times daily). Because the number of "several times a day" responses was insufficient $(n=3)$, the " 1 time/day" and "several times a day" responses were combined. Statistically significant differences in mean ranges/mean scores of menstrual pain between those who did not eat salty snacks, who ate up to 3 times/month, 1 - 2 times/week, 3 - 6 times/week, and 1 time/day or several times daily were not found.

To examine the effect of orgasm frequency on menstrual pain, the Kruskal-Wallis test was used to examine statistically significant differences in the mean ranges/mean scores of responses to the question about painful menstruation as a function of orgasm frequency. Statistically significant differences in menstrual pain were found between respondents who experience orgasms differently (KW $=12.885$; $p$
$=0.024)$. On average, respondents who experience orgasm less than 1 time/week (MR $=346.93), 1$ time/ month or less ( $M R=358.28$ ), and those who have not experienced orgasm in the past six months have the least menstrual pain (Table 7 ).

The Kruskal-Wallis test was also used to test for statistically significant differences in mean ranges/mean scores for menstrual pain according to the hour at which respondents went to sleep (6 groups). We found statistically significant differences in the level of pain as a function of bedtime ( $\mathrm{KW}=12.295 ; \mathrm{p}=0.0150 .05$ ). Respondents who went to bed at 1 a.m. or later had the highest mean pain response rate ( $M R=433.65$ ), and respondents who went to bed before 10 p.m. had the lowest mean menstrual pain response rate (MR = 346.30). Similarly, respondents who went to bed between $10 \mathrm{pm}$ and $11 \mathrm{pm}$ had a relatively low mean response rate for menstrual pain ( $M R=371.43)$.

To test the influence of menstrual perception on menstrual pain, we used the Kruskal-Wallis test to examine statistically significant differences in mean responses to the question about painful menstruation, according to perception of menstruation (positive, negative, neutral attitude). Statistically significant differences were found in the mean ranks/ means of respondents' answers to the question about painful menstruation according to perceived menstruation ( $\mathrm{KW}=76.635$; $\mathrm{p}$ 0.001). On average, menstrual pain was perceived most strongly by respondents who answered "I do not like it, I wish I did not have it"). Respondents who had a positive ("It's something natural, feminine, I am proud and happy to have it.") or neutral ("I do not care, it comes and goes.") attitude towards menstruation had lower pain scores compared to the group with a negative attitude (the average rank scores of pain are lower than in the group with a negative attitude - MR = 


\section{Table 8. Kruskal-Wallis test of menstrual pain according to menstrual perception}

\begin{tabular}{|c|c|c|c|c|}
\hline $\begin{array}{c}\text { How painful is your } \\
\text { menstruation on average (last } \\
6 \text { months) }\end{array}$ & $\begin{array}{l}\text { It is something natural, feminine, I am } \\
\text { proud and happy to have it. }\end{array}$ & f & MR & KW \\
\hline & It's annoying, but that's the way it has to be. & 254 & 358,46 & \multirow{4}{*}{$\begin{array}{c}76,635 \\
(p<0,001)\end{array}$} \\
\hline & I don't like it, I wish I didn't have it. & 351 & 418,77 & \\
\hline & I don't care, it comes and goes. & 57 & 557,54 & \\
\hline & $\begin{array}{c}\text { It is something natural, feminine, I am proud and } \\
\text { happy to have it. }\end{array}$ & 112 & 268,82 & \\
\hline
\end{tabular}

358.46 for a positive attitude and MR $=268.82$ for a neutral attitude) (Table 8).

Because stress was a numerical variable in our case, we used the nonparametric Spearman correlation test to determine the effect of negative stress on the occurrence of pain compared with the above tests. We examined whether there was a statistically significant relationship between menstrual pain ratings and the amount of negative stress experienced in the past six months. We found that there was a statistically significant association between the assessment of menstrual pain and the level of negative stress, which was very weak and positive $(r=0.169 ; p 0.0010 .05)$. Respondents who had experienced more negative stress in the past six months rated their menstrual pain as more severe (Table 9).

Statistically significant differences were found using the Mann-Whitney test, namely that the women who had already given birth had statistically significantly less menstrual pain than those who had not yet given birth $(p=0.05)$.

To test the influence of menstrual perception on menstrual pain, we used the Kruskal-Wallis test to test for statistically significant differences in the means of responses to the question about painful menstruation according to the menstrual perception (positive, negative, neutral attitude). We found statistically significant differences in the mean scores of responses to the question about painful menstruation $(p=0.05)$ according to the type of menstrual perception, i.e. the highest level of menstrual pain was experienced on average by those women who experienced menstruation negatively. Those women who have a neutral-negative attitude towards menstruation expressed a moderate to high level of pain on average, a moderate to low level of pain was expressed on average by respondents who have a positive attitude towards menstruation. Those with a neutral attitude towards menstruation expressed the lowest level of menstrual pain on average.

We used the Spearman correlation test to examine whether there was a statistically significant relationship between ratings of menstrual pain and levels of negative stress. We found that there was a statistically significant relationship between menstrual pain ratings and levels of negative stress $(p=0.05)$, and a very weak and positive one $(r=0.169)$, meaning that those women who experienced more negative stress in the past six months also rated their menstrual pain higher.

\section{Discussion}

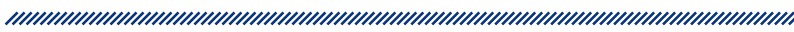

We found that the average pain of the respondents was 4.96 and was highest on the first day of menstruation (5.23). The highest pain scores were reported by women who went to bed after 1 p.m. in the morning, by women

\section{Table 9. Spearman's correlation test of menstrual pain according to the level of negative stress}

On average, how painful is your menstruation (last 6 months)
How would you rate the degree of negative stress you have experienced in the past 6 months?

On average, how painful is your menstruation (last 6 months)

\begin{tabular}{cc}
\hline$p$ & $p<0,001$ \\
$n$ & 773
\end{tabular}


who experienced or had not yet experienced orgasm daily or four to six times per week, and by women who had not yet experienced childbirth. Higher pain scores were also reported by women who had negative attitudes toward menstruation and by women who reported higher levels of negative stress.

Women who go to bed before 10 p.m., who have fewer than one orgasm per week, or who have orgasms once a month or less often reported lower pain scores on average. Pain is also lower in women who have already given birth, who have a neutral attitude toward menstruation, and who experience less negative stress. Previous research has shown that women whose mothers and sisters also had painful periods were significantly more likely to have painful menstruation $2,4,9,11,13$. Combined with our finding that women with negative attitudes toward menstruation are more likely to experience pain, we can conclude that pain may also be the result of learned behaviours that women have adopted from family members, rather than being influenced solely by genetic or physiological factors ${ }^{2,13}$. The presence of pain in family members could also be influenced by exposure to the same or similar lifestyle habits, which we assume are usually similar in family members. The results regarding menstrual experience could also be interpreted differently, and a negative attitude toward menstruation could be established precisely because of the greater pain a woman experiences during menstruation, rather than the other way around. In any case, we believe that the relationship between dysmenorrhea and family and psychological factors should be further explored ${ }^{2,9,13}$. Women who report higher levels of negative stress describe more painful menstruation than women who experience lower levels of negative stress. Based on the results, we were able to confirm that positive or negative perceptions of menstruation and experiencing negative stress have an impact on menstrual pain. However, we cannot yet say with certainty whether pain is primary and thus negative perceptions of menstruation or vice versa. Researchers describe that women who consume more sugar and salty snacks have more painful menstruation, but we have not been able to confirm this association ${ }^{12}$. This result could also be influenced by an incomplete questionnaire. Therefore, we believe that a more detailed discussion would require studies that have a narrower scope and focus only on diet in relation to menstrual pain. We were unable to demonstrate a statistically significant relationship between physical activity and pain level in our study, which contradicts the results of foreign authors who describe the positive effect of moderate physical activity on menstrual pain in their studies ${ }^{12-14}$.

\section{Conclusion}

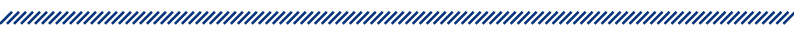

Dysmenorrhea is a very common gynaecological problem that causes great difficulty for women in their childbearing years. We have focused on primary dysmenorrhea and its associated lifestyle factors. In relation to pain, we looked at family, exercise, sexuality, sleep, diet and stress. The aim of our study was to determine if certain lifestyle factors have an impact on the severity of menstrual pain or primary dysmenorrhea. The results of the study confirmed statistically significant associations between sleep, sexuality, stress, menstrual perception and menstrual pain.

\section{References}

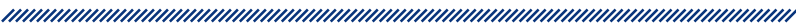

1. Arafa AE, Senosy SA, Helmy HK, Mohamed AA (2018). Prevalence and patterns of dysmenorrhea and premenstrual syndrome among Egyptian girls (12-25 years). Middle East Fertil Soc J 23(4):486-90. doi: 10.1016/j. mefs.2018.01.007.

2. Abu -Martínez E, Onieva-Zafra MD, Parra-Fernández ML (2018). Lifestyle and prevalence of dysmenorrhea among Spanish female university students. PLoS ONE 3(8). doi: 10.1371/journal.pone.0201894.

3. Iacovides S, Avidon I, Baker FC (2015). What we know about primary dysmenorrhea today: a critical review. Hum Reprod Update 21(6):762-78. doi: 10.1093/humupd/dmv039.

4. Abdel-Salam DM, Alnuman RW, Alrwuaili RM, Alrwuaili GA, Alrwuaili EM (2018). Epidemiological aspects of dysmenorrhea among female students at Jouf University, Saudi Arabia. Middle East Fertil Soc J 23(4):435-9. doi: 10.1016/j.mefs.2018.08.001.

5. Karthik C, Preetha S, Priya J (2018). Impact of dysmenorrhea on academic performance in college girls. Drug Invent. today 10(11): 2238-40.

6. Omidvar S, Bakouei F, Amiri FN, Begum K (2016). Primary dysmenorrhea and menstrual symptoms in Indian female students: Prevalence, impact and management. Glob J Health Sci 8(8). doi: 10.5539/gjhs.v8n8p135.

7. lacovides S, Avidon I, Bentley A, Baker FC (2014). Reduced quality of life when experiencing menstrual pain in women with primary dysmenorrhea. Acta Obstet Gynecol Scand 93(2): 213-7. doi: 10.1111/aogs.12287. 
8. Laszlo KD, Gyorffy Z, Adam S, Csoboth C, Kopp MS. (2008). Work-related stress factors and menstrual pain: a nation-wide representative survey. J Psychosom Obstet Gynaecol 29(2):133-8.

9. Abu Helwa HA, Mitaeb AA, Al-Hamshri S, Sweileh WM (2018). Prevalence of dysmenorrhea and predictors of its pain intensity among Palestinian female university students. BMC Womens Health 18(1):18. doi: 10.1186/ s12905-018-0516-1.

10. Bajalan Z, Alimoradi Z, Moafi F (2018) Nutrition as a potential factor of primary dysmenorrhea: A systematic review of observational studies. Gynecologic and obstetic investigation 84:209-224. doi: 10.1159/000495408

11. Muluneh AA, Nigussie TS, Gebreslasie KZ, Anteneh KT, Kassa ZY (2018). Prevalence and associated factors of dysmenorrhea among secondary and pre- paratory school students in Debremarkos town, North-West Ethiopia. BMC Womens Health 18(1):57. doi: 10.1186/s12905-018-0552-x.

12. NajafiN, KhalkhaliH,MoghaddamTabriziF,ZarrinR(2018). Major dietary patterns in relation to menstrual pain: a nested case control study. BMC Womens Health 18(1):69. doi: 10.1186/s12905-018-0558-4.

13. Ju H, Jones M, Mishra G (2014). The prevalence and risk factors of dysmenorrhea. Epidemiol Rev 36:104-13. doi: 10.1093/epirev/mxt009.

14. Abadi Bavil D, Dolatian M, Mahmoodi Z, Akbarzadeh Baghban (2018). A comparison of physical activity and nutrition in young women with and without primary dysmenorrhea [version 1; referees: 2 approved, 1 approved with reservations]. F1000Res 7:59. doi: 10.12688/ f1000research.12462.1. 


\section{UTJECAJ NAČINA ŽIVOTA NA PRIMARNU DISMENOREJU}

1 Monika Finžgar

2 Raja Dahmane Gošnak

3 Borut Poljšak

4 Andrej Starc

1 Faculty of Health Sciences, University of Ljubljana

2 Faculty of Health Sciences, University of Ljubljana, Department of Biomedicine in Health Care

3 Faculty of Health Sciences, University of Ljubljana, Laboratory for Oxidative Stress Research

4 Faculty of Health Sciences, Department of Public Health, Slovenia, University of Ljubljana

\section{Sažetak}

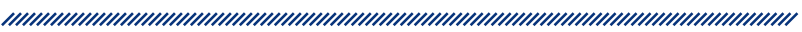

Uvod: Dismenoreja, također poznata kao bolna menstruacija, uobičajena je ginekološka dijagnoza s kojom se susreće većina žena fertilne dobi. Dismenoreja je još uvijek neshvaćeno stanje i većina žena prihvaća je kao normalan dio menstruacijskog ciklusa. Bol ima snažan utjecaj na dobrobit i može ozbiljno utjecati na kvalitetu života.

Metode: Ispitivanje je provedeno na ispitanicama putem online upitnika u periodu između svibnja i srpnja 2020. Primijenjeni su Shapiro-Wilkov, MannWhitneyjev i Kruskal-Wallisov test te neparamedicinska statistička analiza primjenom Spearmanova koeficijenta korelacije. Razina statističke značajnosti postavljena je na $\mathrm{p}=0,05$.

Rezultati: Uzorak se sastojao od 774 žene. Ispitanice koje su već rodile statistički značajno manje osjećaju men- struacijske bolove $(M R=270,36$; VR $=67859,50)$ od ispitanica koje nisu rađale ( $M R=402,06$; VR $=184545,50)$. $\mathrm{U}$ prosjeku najmanje bolne menstruacije imaju ispitanice koje dožive orgazam manje od jedanput tjedno (MR $=346,93)$, a najbolnije menstruacije imaju ispitanice koje doživljavaju orgazam svaki dan ili četiri do šest puta tjedno (MR $=427,18)$. Ispitanice koji odlaze na spavanje u jedan sat ujutro ili kasnije imaju najveću srednju vrijednost osjećaja jačine boli $(M R=433,65)$, a najnižu one koje odlaze na spavanje prije 22 sata (MR $=346,30)$. Najvišu srednju vrijednost osjećaja jačine menstruacijske boli imaju ispitanice koje imaju negativan stav prema menstruaciji ( $M R=557,54)$, a najnižu ispitanice s neutralnim stavom $(M R=268,82)$.

Zaključci: Rezultati potvrđuju statistički značajnu vezu između sna, seksualnosti, stresa, menstrualne percepcije i menstruacijske boli.

Ključne riječi: menstruacijska bol, način života, dismenoreja, čimbenici načina života 